\title{
ANCIENT HISTORY
}

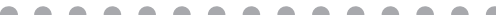 \\ ONCE AGAIN TO THE QUESTION OF OCTAVIAN AUGUSTUS' PRINCIPATE}

\begin{abstract}
In the article on the basis of scientific publications of Russian and foreign scientists, as well as information of ancient authors, there is the analysis of little-studied problems of the formation of Roman Caesarism not only from formal legal, but also socio-economic and political points of view which objectively influenced the transformation of the Republican system in Rome. The author tries to resolve the question whether Octavian desired power for his personal elevation, and the formation for this the monarchical form of government, as many researchers believe, or his purpose was the development of the Republican system which was adequate to the challenges of time? Were the powers of August different from powers of other Roman magistrates? The article proposes a new vision of the purposes and tasks of the propaganda war between Antony and Octavian, as well as the peculiarities of Augustus acquisition of prestige and authority and powers of the tribune and consul, which became the basis of his Imperial power.
\end{abstract}

Keywords: Principate, the magistrate, the Senate, the Roman comitia, Tribune, Consul, Emperor, province, the law, propaganda war.

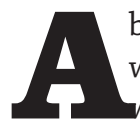

bout the Principate of Octavian Augustus a considerable number of works have been, from the works of Titus Labien and Azilian Pollio who lived during the reign of the Princeps. This is not surprising, because the formation of the Principate is one of the key problems of ancient history. Back in the middle of the last century, N. A. Mashkin wrote that very 'difficult to name another problem of ancient history, which is discussing in historical literature with such constancy as the history of the Principate' ${ }^{1}$. However, as imagine, this problem so until the end not investigated, as a more attentive study we can reveal a number of 'white spots'.

In particular, the question of the origin of the power of August is resolved unilaterally, mainly from a formal legal point of view, based on which the conclusion is been made about the degree of legality of his powers in the sphere of state administration. However, even within the framework of this approach, not all the nuances of Octavian coming to power were been revealed deeply enough. In addition, as a rule, in their works, researchers focus on the subjective factor in the sense of Octavian desire for sole power. Of course, this played an important role in the formation of the Principate. However, we must not lose sight the objective side, which is associated with changes in the socio-political and economic situation in Roman society at the end of the late period of the Republic. In this regard, the actual side of the problem remains open, which reveals little-known facts of the usurpation of power by Octavian

\footnotetext{
MASHKIN 1949, 3.
}

\section{Valentin Medvedev}

Togliatti State University

medved.valentin@rambler.ru

DOI: $10.14795 /$ j.v6i4.472

ISSN 2360 - 266X

ISSN-L 2360 - 266X 
as the result of the civil war, in which various social strata of society, pursuing their interests, were involved.

Also one-sided revealed the essence of the propaganda war between Octavian and Antony, which requires deeper analysis. Also of interest is the question of whether the power of Octavian-Princeps differed from the power of the top ordinary magistrates, and if different, then how, and on what it was based? Why the tribune powers granted to Octavian in stages? At last, has Octavian needed personal power for his personal exaltation, as many researchers believe, or his aim was in obtaining of power for using of it in adequate conditions of his time of the state and political system of Rome development? These conditions consisted in the complexity of the management of a vast Roman power, which included many different countries and peoples, and it had a huge number of slaves who had to be keeping in obedience.

The article has the information of ancient authors who shed light on the formation and consolidation of the Principate of Octavian Augustus de jure and de facto. It is the writings of Dio Cassius 'Roman history', books 51 and 53, 'The Roman history' of Appian, 'History against the pagans' of Paul Orosius, 'Res gestae' as a kind of political Testament of Augustus.

Also used fragments of 'History' Gaius Sallustius Crispus, 'The annals' of the Anniy, 'Life of the twelve Caesars' by Suetonius and many other sources, and Digesta. For a more in-depth study of the formation of Roman Caesarism, the Principate of Octavian Augustus should be considered not only from the formal legal point of view, but also from the actual point of view ${ }^{2}$. By the author's opinion, it is the most significant, because, as lawmaking practice shows, laws always follow the already established or tended to develop social relations. The legislators under the pressure of certain circumstances only have to fixate them in the legal system of the state. In this regard, it should be noting that the trend towards the centralization of power and management in Ancient Rome as a special stage in the development of authoritarianism has already clearly manifested itself in attempts to establish sole power by the predecessors of Octavian. Thus, contemporaries of Gaius Gracchus accused him in the quest for Imperial power, the dictators Marius, Sulla and the rebellious Catiline also had ideas of implementing of autocratic management. To one-man rule sought Pompey and Caesar, and later Mark Anthony. The greatest contribution to this process made Sulla and Caesar ${ }^{3}$.

All this, and especially the creation of the first triumvirate in the $60 \mathrm{~s} \mathrm{BC}$, directed against the Senate, testified to the crisis of the state system of the Republic and the tendency to turn it into a monarchy. However, the March ides of $44 \mathrm{BC}$, when Caesar was killed, showed that the time of establishing a monarchical system in Rome, where the Republican traditions were still strong enough, has not yet come. Therefore, Caesar attempt to establish a military dictatorial form of government in the image and likeness of the Hellenistic monarchy was not successful. At

\footnotetext{
2 According to Gruen, in the time of Octavian Augustus, the term 'Principate' was not yet used in the state sense. He entered the political life of the Empire only at the turn of the I-II centuries. GRUEN 2007, 33.

3 STEIN-HÖLKESKAMP 2013, 429-446; SANTANGELO 2007.
}

the same time, his murder led to a new civil war, and in the conditions of domination in the society of military force, the caesaristic tendency continued to develop. In RGDA 2 Augustus proclaimed: 'I lawfully expelled the people who killed my father, punishing them for their crime, and then when they started a war against the state, I defeated them in two battles' ${ }^{\text {. }}$

In accordance with the information of Appian in historical science, it is entrenched notion that the turning point in this process was the law of Publius Titia, adopted in November $43 \mathrm{BC}$ by the Roman comitias under pressure introduced into Rome legions and the Praetorian cohorts. This law was approved by the Senate which being under the influence of triumvirs ${ }^{5}$. As a temporary measure necessary ostensibly 'for the establishment of the Republic', this law legally formalized the second triumvirate, which represented the new magistracy. This law gave Mark Antony, Emilia Lepidus and Gaius Caesar Octavian unlimited powers for a five-year term. Subsequently, this term has been extended until the end of December 33 BC Because of the agreement between the dictators, concluded in the city of Torrente.

As is known, the first triumvirate did not receive legislative consolidation and approval in the Roman comitia. However, this did not prevent Julius Caesar, with the help of his loyal legions, united by a soldier's moral, which forced them to support their commander ${ }^{6}$, and with the support of certain social strata of the population to establish his dictatorship. On this basis, with a significant degree of certainty, we can to claim that the absence of this law unlikely prevented to achieve the power by Octavian. Not only the slave-owning elite, but also all citizens were waiting for establishing long-awaited peace, so the objectively they should have been to support August operating under proclaimed by him slogan 'Pax Romana'. In this regard, the formation of the Principate can be considered not only as the evolution of the political system of Rome. According to N. Ah. Mashkin, it also can be considered as a social revolution, as the Roman community-civitas has become a huge Empire, within which matured new social relations ${ }^{7}$. This law, in essence, only legalized the Caesar's sentiments that arose in society and, without playing a decisive role in the capture of power, nevertheless, significantly accelerated the transformation of the state system, putting it on the legislative basis. Obviously, taking into account the sad fate of Caesar, the triumvirs simply planned to create a formal appearance of Republican legality, and, consequently, support for their dictatorship by Roman citizens.

As historical experience has shown in conditions of the need centralization of the management, the triumvirate could not be a sustainable magistracy. The contradictions between its participants, who relied on the loyal troops and support of the various groups of the Roman-Italian aristocracy, who pursued their own interests, had to lead and led to a civil war. In the end, power was in the hands

Qui parentem meum trucidaverunt, eos in exilium expuli iudiciis legitimis ultus eorum facinus, et postea bellum inferentis rei publicae vici bis acie; $\mathrm{DE}$ JONG 2019, 20.

App. B C. IV, 7.

URECHE 2014, 3-7.

MASHKIN 1949, 505-506. 
of the strongest dictator. However, according to Cooley the rise to power of Octavian Augustus and the giving of the long-awaited 'Pax Romana' by him for people was associated with civil wars that took the lives of thousands of Roman citizens ${ }^{8}$.

As we know, the collapse of the second triumvirate began after the defeat, which the triumvirs inflicted to the Republican Party in Senate, after which a struggle for power began between them. Its first stage was the relatively peaceful elimination by Octavian their weakest ally, the elderly Lepidus from political scene. In the second stage, a decisive battle was approaching between Octavian and Antony, which was to decide the fate of the Roman society and state.

The victory in this battle of the Western or Eastern dictator was largely dependent on the legitimization of their power. This was to ensure support for their policies by legions and the majority of representatives of the Roman-Italian nobility. Both triumvirs to win the sympathy of the society launched a large-scale propaganda campaign the slogans and directions of which the works of many researchers well discover ${ }^{9}$. However, the scientific interpretation of this propaganda war researchers implement on the information of ancient authors, but most of them wrote their works mainly in corresponding with the official point of view established by Octavian. According to Plutarch, the initiator of this propaganda war was Octavian, who gradually subordinated to himself the Senate and the italic population and by his accusations, he strived to 'irritate the Romans' against Anthony. Anthony had no choice but to make counter-accusations against Caesar. According to Plutarch, not remaining in debt, Antony all the time sent his people with retaliatory accusations ${ }^{10}$.

Almost all modern researchers in the analysis of the propaganda war between Octavian and Antony concentrate their attention on the Antonian 'Republican' and 'monarchical' Octavian features of the propaganda actions of the triumvirs. However, according to the author, in the second half of the 30s BC. 'party' ideology as such, has not been used, because the 'Pompeian' and 'Caesarian' slogans have lost their popularity among the population. Pompey's party was destroyed, and revenge for Caesar was a thing of the past. In this regard, the triumvirs mainly used personal libel and lampoons, which, in the opinion of C. Pelling, in the period of the late Republic were widely used in political struggle ${ }^{11}$. In this regard, the analysis of this propaganda campaign should be quite critical and it is necessary more detailed study the actions of the rival triumvirs.

The essence of the mutual accusations of the two dictators was as follows. According to Plutarch ${ }^{12}$, Antony accused Octavian of having personally appropriated the troops and possessions of the Sextus Pompey and the deposed Lepidus, which was supposed to belong to both of them in equal shares. Demanding half of all the described

\footnotetext{
${ }_{8}$ COOLEY 2009, 4-6; 50-51.

9 BROADBENT 2012; CHARLESWORTH 1929; TARN 1932; CHENYSHOV 1994; GURVAL 1998; NIMIS 2004; PELLING 2001; SCOTT 1933; TYLDESLEY 1998 and others.

10 Plut. Ant. 55.

11 PELLING 2005, 12

${ }_{12}$ Plut. Ant. 55.
}

above, Antony essentially put forward claims to control of Italy. According to I. Kromayer, he made a big mistake, as the Italic population was afraid of new land confiscations with his hand. This allowed Octavian, who hoped for the support of the cities, to reject Anthony's demands in a rather rough form $^{13}$.

Octavian, in turn, was reproaching Anthony that he ordered to kill Sextus who was not a part of murderers of Julius Caesar and therefore received a pardon, and that Antony illegally owned Egypt, as had no mandate for its management. In addition, violating the Treaty between Rome and Armenia he captured the tsar of Armenia and thus allegedly 'disgraced Rome'. Octavian, in addition, demanded half of the asset received by Antony, especially the return of what he gave Cleopatra and her children as part of the socalled 'Alexandrian gifts' 34 BC.

The essence of these 'gifts' was that in the autumn of this year in the gymnasium Alexandria Eastern triumvir declared Cleopatra as a 'Queen of kings' and granted to her Egypt and Cyprus in the manage. According to Dion Cassius and Plutarch, her eldest son Caesarion received the title of her co-ruler. The son of Cleopatra and Antony six-year-old Alexander Helios was to become the ruler of Armenia, Media and Parthia, and his twin sister Cleopatra Selena - the ruler of Libya and Cyrenaica. The youngest son of Cleopatra and Antony Ptolemy Philadelphos obtained the right to manage Cilicia and Celesyria ${ }^{14}$.

Octavian presented to public opinion the 'Alexandrian gifts' as the illegal provision by the mad in love Antony the domain of the Roman people to Egyptian tsarina, who was not Roman female citizen. This was unsubstantiated confirmed by many ancient authors. According to some researchers, August was supported in this question by representatives of very influential social groups interested in the exploitation of the Eastern provinces ${ }^{15}$.

At the same time, as it seems that Anthony accusation by Octavian of 'Alexandrian gifts' was nothing more than a clever political step, since Rome used the practice of such 'gifts' before. For example, in 129 BC for helping to suppress the Pergamum revolt Senate granted Mithridates V the Great Phrygia, and the tsareviches of Cappadocia received Phoenicia and Lycaonia ${ }^{16}$. A similar action was held in the 70 s BC in relation to the Galatian tetrarch Deitra, awarded the tzar title and the new lands for support Rome in the war against Mithridates VI. Taking this into account, it can be stated that by transferring to Cleopatra in $36 \mathrm{BC}$ Phoenicia and Cyprus, as well as part of the lands of Judea, Cilicia, Nabataean Arabia, Antony apparently foresaw the inevitability of the struggle with Octavian and acted within the Roman political tradition for the reorganization of the Eastern region in their interests. According to J. B. Tsirkin, to strengthen his Eastern front Antony wanted to create a conglomerate of States that must be managed subject to him the house of the Ptolemies. This view partially or fully support other researchers ${ }^{17}$.

\footnotetext{
${ }_{13}$ KROMAYER 1898, 51.

${ }^{14}$ Cass. Dio. XLIX. 40.2-41.3; Plut. Ant. 54.

5 SWOBODA 1932, 96; SYME 1939, 290; PARIBENI 1950, 311.

${ }^{6}$ Just. XXXVII.1.2.

TSIRKIN 2006, 289; REINHOLD 1981-1982, 97; LINDSAY 1936, 274;
} 
However, the author believes that in $34 \mathrm{BC}$, the contradictions between the Eastern and Western triumvirs were not yet so acute, and Antony, conducting 'Alexandrian gifts', is unlikely to prepare for an active armed struggle with Octavian. On the contrary, at this time he was busy thinking about conquering Parthia, so he needed allies, which he received due to the reorganization of management in the East. So, in addition to the 'gifts' to Cleopatra, he dismissed the rulers of Pontus, Cappadocia and Galatia, giving power in these kingdoms to his supporters ${ }^{18}$. After the conquest of Grand Armenia, a large part of its territory, he also handed in $33 \mathrm{BC}$, his supporter Artavazd Atropatena ${ }^{19}$.

Thus, as it seems, and as confirm by the judgment of ancient authors, its main business in the East Antony considered the struggle with the Parthians ${ }^{20}$. A certain proof of this is the fact that the first 'gift' to Cleopatra Antony made on the eve the Parthian campaign, because need of help Ptolemaic Egypt ${ }^{21}$.

In addition, while reorganizing the administration in the East, Antony acted within the framework of the law and the powers of the dictator directly arising from it. As required by law, he appealed to the Senate, which was authorized to approve the measures taken to change the system of government in the East ${ }^{22}$. As Dion Cassius evidenced, if Anthony had really been preparing for a war with Rome, such treatment would have seemed pointless. In addition, according to $S$. Akhiev, who is referring to the evidence of Dion Cassius and Plutarch $(\delta \omega ́-\sigma \varepsilon ı v \text { vं } \varepsilon \dot{\varepsilon} \sigma-\chi \varepsilon-\tau o)^{23}$, 'Antony not appointed really children as rulers, but he only promised this to them'24.

By performing the 'Alexandrian gifts' Anthony has done nothing new. According to M. Reinhold, he only continued the policy of Julius Caesar in the East in relation to the dependent kingdoms, when he in virtue of his dictatorial prerogatives settled on behalf of the Roman people dynastic crisis in Egypt, appointing Cleopatra co-ruler her brother ${ }^{25}$. Herewith, according to D. Bround study, namely the Senate approved the will of Ptolemy $\mathrm{XII}^{26}$. In connection with this Antony also appealed to this body for approval of his 'gifts'.

Thus, the author considers that Mark Antony aspired during this period not to fight against Octavian Augustus, but to centralization of management of the Roman provinces and dependent kingdoms in the East for preparation of new war with the Parthian state. In addition, the author supports the point of view of L.N. Bogomazova that his reorganization of management unequivocally assumed after the conquest of Parthia the further peaceful incorporation of Egypt with the territories attached to it into the Roman Empire ${ }^{27}$. For this, obviously, was carried out 'Alexandrian gifts', that lulled the vigilance of the power-loving Egyptian Queen and made

KRIST 1997, 84; BENGTSON 1982, 352; GOLDSWORTHY 2010, 678; PELLING 2005, 40-41; REHAK 2006, 36-37.

${ }^{18}$ Cass. Dio. XLIX. 32. 3.

${ }_{19}$ Cass. Dio. XLIX. 44. 1-2; Debvois 2008, 125-126.

${ }^{20}$ App. BC. V. 95.

${ }^{21}$ Plut. Ant. 36; TYLDESLEY 2008, 154

${ }^{22}$ Cass. Dio. XLIX. 41. 4; BRAUND 1984, 136-137. [17]

${ }^{23}$ Dio Cass. XLIX. 41. 1-3; Plut. Ant. 54.

${ }^{24}$ AKHIEV 2009, 244.

${ }^{25}$ REINHOLD 2002, 57

26 BRAUND 1984, 136.

27 BOGOMAZOVA 2012, 33-34.
Egypt a faithful ally of Rome. According to Dion Cassius, having received the 'gifts', Cleopatra became sure in the opinion that to be an ally of Rome is very profitable ${ }^{28}$. With that, none of the ancient authors do not mention that the Egyptian Queen knew about the second part of the Antony plan, which he intended to implement after the conquest of Parthia.

Thus, Antony and Octavian as it seems to have invested in the 'Alexandrian gifts' and as a whole in the reorganization of the management in the East at all different meanings, but the ancient sources, for obvious reasons, reflected only the official version established by the winning party. Naturally, Octavian was unprofitable to announce the second version, because the possible victory of Antony in the war with the Parthians and the subsequent inclusion of Egypt with all its territories in the Roman Empire would make him the undisputed leader.

It seems that a various meaning the opposing sides invested in such act of 'Alexandrian gifts' as Anthony made a public proclamation of Caesarion the blood son of Caesar and Cleopatra. Dion Cassius believed that this was done in order to oppose Caesarion to Octavian, who was only an adopted son in the Julius genus ${ }^{29}$. According to S. N. Achieve, this judgment 'was approved as axiom in modern historiography, and the Antony idea of the contraposition native (legal) son -Caesarion to adopted son - Octavian is firmly established in modern historical literature in the context of the propagandistic war between triumvirs ${ }^{30}$. This is confirming by a whole number of studies ${ }^{31}$. Thus, in the historiography the concept was shaped, in which the propaganda of Antony opposed Octavian to Caesarion, with the aim to convince the public that Caesarion, not Octavian had the right to the political inheritance of Julius Caesar.

However, the author does not quite agree with this statement. Obviously, the main content of the propaganda war between Antony and Octavian was that both dictators in their propaganda thought to show the Roman citizens that they are fighting for the establishment of universal peace, the return of society and the state to Republican principles, Republican customs, ideas and values. Each of them tried to prove to countrymen that it is he, and not his opponent is able to implement in practice the claimed slogans. In fact, according to the author, each of them aspired to become an unlimited ruler, and in the propaganda of each of them quite clearly looked through the sprouts of the future Principate, as stated in the works of some authors ${ }^{32}$.

In this regard this contraposition Octavian-Caesarion appears to be need in serious critical analysis as currently found no sources other than personal Dion Cassius judgment, which would indicate the made by Antony contraposition the right Octavian and Caesarion to possession the political legacy of Caesar. In this regard, the question arises, and Antony had whether such plans at all, and if they were, could they be implementing?

\footnotetext{
${ }^{28}$ Cass. Dio. LI. 15. 4.

29 Dio Cass. XLIX. 41. 2.

30 AKHIEV 2009, 243.

3 SCULLARD 1959, 173; LINDSAY 1971, 58, 119 f.; KIENAST 1999, 53; SCOTT 1929,133-141; SCOTT 1933, 36-48; TARN/CHARLESWORTH 1989, 90-98; TARN 1932, 44-149; CHARLESWORTH 1933,173-175.

32 PELLING 2005, 37; SUMI 2005, 199.
} 
Well known, the Roman legislation required the mandatory legalization of inheritance rights through the adoption of the heir in the genus of the testator by approval of this act at the meetings of the people in curias (curiatii ad comitia- lat.), and the adoption had to be carrying out during the life of the testator. In this regard, even Octavian, whom Caesar in his will called the main heir, it was very difficult to realize this right because his adoption was occurring after the death of Caesar ${ }^{33}$. Meeting of the people in curias legislatively approved him as heir only after he brought his troops into Rome in August $43 \mathrm{BC}$, putting pressure on the people's Assembly and Senate ${ }^{34}$.

As for Caesarion, in proclaiming him the rightful son of Caesar, Antony could be at no losing to understand that the chances of Ptolemy Caesar on political legacy of his father were practically zero. First, Caesarion was not a Roman citizen. Secondly, under Roman law, he was recognizing as bastard. According to Suetonius, the Senate, which, Anthony appealed for the recognition of Caesarion as a son of Caesar, was not entitled to include him in the genus of Julius ${ }^{35}$. According to Roman hereditary law, at that time the supremacy of agnatic kinship over the cognatic was established. This could not give the son of Cleopatra and Caesar the right to inherit the property and the clientele of the father ${ }^{36}$. In this regard, Antony's pretension to recognize the political rights of Caesarion was groundless. The Senate could only confirm Cleopatra's son as ruler of Egypt, but and this was not done.

But then the question arises, why then Antony needed so stubbornly to prove that Caesarion is the son of Caesar? This he expressed in his address to the Senate, declared it during the 'Alexandrian gifts', mentioned it in his will, finally, the fact of blood kinship of Caesar and Caesarion he asked to confirm the colleagues of the late dictator and supporters of Octavian - Guys Oppius and Guys Mattie ${ }^{37}$. The latter, if we assume that Antony saw his enemy in Octavian, seems generally pointless, that was confirmed in practice. Oppius, who stood closely to Octavian and played an important role in his elevation on the steps of power, apparently at the direction of Octavian quite unexpectedly for Antony issued a publication in which he denied the fact of the kinship Caesarion and Caesar. As H. Heinen pointed, Oppius, who knew the details of Caesar's personal life very well probably either out of a sense of self-preservation or affection to Octavian, played up the role of hypocrite ${ }^{38}$. Or as author is quite allowing, Oppius knew that Caesarion was not really Caesar's son?

Finally, with regard to the will of Antony, which was stored in the temple of the Vesta goddess, and which at the insistence of Octavian in violation of Roman law been read out in the Senate and the people's Assembly during the life of the Eastern triumvir. This at first turned from Octavian some of his adherents away, not to mention Antony's supporters. However, in subsequent effect was truly stunning - most

\footnotetext{
33 SOUTHERN 1998, 35.

${ }^{34}$ App. BC. III. 94; Dio Cass. XLVI. 47. 4-6.

35 Suet. Jul. 52. 2.

36 Gaius. Inst. I. 48-111.

${ }^{37}$ Suet. Iul. 52. 2; Dio Cass. XLIX. 41. 2., L. 3. 5; Plut. Ant. 54.

38 HEINEN 1969, 195.
}

of the Italian nobility, including senators turned away from Antony, because many sincerely believed that if he ruled, their city would be given to Cleopatra, and the capital moved to Egypt ${ }^{39}$.

The will have given into the hands of Octavian a huge trump card, so some researchers have even doubted its authenticity ${ }^{40}$. In will, according to Suetonius Anthony not only confirmed that Caesarion is the son of Caesar, but also declared childrens of Cleopatra his heirs ${ }^{41}$, which was contrary to Roman law and could not entail any legal consequences. The children of Antony and Cleopatra, as well as the Egyptian Queen herself, were not Roman citizens. Under Roman law, they could not be heirs either in property or in a political meaning, which, however, D. Kinast disputes ${ }^{42}$

Thus, the actions of the Anthony's regarding the recognition Caesarion by Caesar's heir at first vision seem not only illogical but also illegal. Nevertheless, some researchers, for example, K. Meiklejohn, saw in it a certain logic. The use by Antony for propaganda purposes the name of Caesar's son was to serve the purpose of attraction the Romans to his side, K. Meikljohn believed as some modern scientists ${ }^{43}$. However, if follow the ancient authors, we can see that the problem of the opposition of Caesarion and Augustus in most cases was not publicly raising by Antony, which would be quite understandable in the context of the propaganda war, but by Octavian himself, who sought to instigate Roman citizens against the eastern Triumvir. Accusing Antony in an illegal effort to legalize the status of the son of the foreigner queen in the genus of Juliuses, he in every way emphasized the low falling of the eastern Triumvir. He drew the Romans' attention to the fact that Antony fell under the influence of the Egyptian czarina became a slave to her desires and recognized the barbarous eastern way of life, unworthy of a Roman ${ }^{44}$.

However, why did Antony want to get on the recognition of Caesarion as Caesar's son after all? It appears that the reason for this should not be found in the confrontation with Octavian, but in his plans to conquer the East, associated with the reorganization of management in the region and the 'Alexandrian gifts', which extended to all Eastern territories up to India. In this regard, the judgment of S. N. Akhiyev is very interesting. He considers that Antony assigned to Caesarion a role not only the co-ruler of the Egyptian Queen, but also after Cleopatra's death - the Lord of all East in the status 'the king of kings' subordinated to Rome. To do this, it was necessary to recognize the divine origin of the son of Caesar, not only in the East but also in the West. However, if in the East legitimation of his rank was not in doubt, since he was born from the 'sacred marriage' of the divine Cleopatra-Isis and Caesar (deified by the Senate decree in January $42 \mathrm{BC}$ ), the Roman laws did not recognize this marriage. 'In this, as according to the researcher, and was a persistent desire of Mark Antony to introduce to

\footnotetext{
${ }_{39}$ Dio Cass. L. 3. 5, L. 4. 1; Plut. Ant. 58; Suet. Aug. 17. 1.

${ }^{40}$ LINDSAY 1971, 348-349; GRANT 2004, 275.

${ }^{41}$ Suet. Aug. 17. 1.

${ }^{42}$ KIENAST 1999, 53.

${ }^{43}$ MEIKLJOHN 1934, 192; BROADBENT 2012, 63; PELLING 2001, $296-$ 299; MARTYNOV 2007, 362-367.

${ }^{44}$ ACHIEV 2001, 96-97.
} 
the Roman public consciousness the idea of blood kinship Ptolemy XV'45.

In the propaganda war, Octavian used other very effective tricks. For example, the murder of Sextus Pompey, he presented as a purposeless cruelty contrary to the principles of clemency ${ }^{46}$. Octavian understood that this act would have long-term consequences, because according to the Van Den Hengel, with which one can quite agree, the application of honors or sanctions of memory contributes to the creation of a positive or negative impression of a person ${ }^{47}$. August had calculated exactly that, accusing Anthony in this cruel act, he gets guarantees of a certain support of those who at the time was sympathized with the son of Pompey.

Despite the fact that Octavian was the initiator and the most active party of the propaganda war, as it seems, Anthony also cannot be considering as an outsider in this war. Together with military preparations for the crucial fighting, he did a massive ideologization of the public opinion. The most significant step in his propaganda, according to Dion Cassius, was his appeal to the Senate after an open break with Octavian in $33 \mathrm{BC}$. In this address, he offered to give up his power if Octavian follows his example ${ }^{48}$. The following year, he made a new appeal to Senate in the hope, obviously, to get support the Republican party. In this appeal, he stated that in case of victory '...he will give up his power and pass all its fullness to the Senate and people'49.

These statements played a significant role in the consolidation of Anthony's supporters, as a result of which Octavian found himself in a difficult situation during the constitutional crisis formed in the beginning of $32 \mathrm{BC}^{50}$. This year at the first meeting of the Senate, which Octavian was not present, the adherents of Antony, the new consuls Domitius Ahenobarbus and Guys Saucier criticized August, and the supporter of Octavian, tribune Nonny Balba in order to prevent negative consequences, remained nothing how to close a meeting. When surrounded by soldiers and friends Octavian appeared on the convened by them new meeting and criticized his opponents, both consuls and many senators, for fear of proscriptions, fled to Antony ${ }^{51}$. Thus, in the state was formed as if two Senates, herewith, as evidenced P. Valman, who studied this problem, about half of the senators (about 400 people), including two consuls, turned out in the so-called 'anti-Senate' of Antony ${ }^{52}$. This allowed the researcher and some other scientists to conclude that the Antonian Senate was a legitimate body and had the right to make any decisions; however, Antony did not take advantage by that ${ }^{53}$. However, such a judgment can hardly accepted, because, according to the Roman political and legal tradition, the Senate had rights to act only in Rome. Antony, obviously, understood this well and therefore did not attempt to conduct through this Senate measures to reorganize the administration in the East and the recognition of Caesarion as the legitimate son of Caesar.

\footnotetext{
45 ACHIEV 2009, 246; ECK 2007, 32-34

${ }^{46}$ LEVI 1951, 130.

47 VAN DEN HENGEL 2009, 328.

${ }^{48}$ Dio Cass. XLIX. 41. 6.

49 Dio Cass. L. 7. 1-2.

50 FADINGER 1969, $270 \mathrm{ff}$

51 Dio Cass. L. 2. 3; L. 2.6

52 WALLMANN 1976, 306

53 SYME 1935, 115.
}

Thus, in the propaganda war, Anthony was in the role of the defeated, which seems to determine his passivity and in further actions in the armed struggle for power. This largely depended on the fact that, according to R. Syme, with which we can agree, he could not fully rely on his supporters, which included quite a significant number of representatives of the Roman aristocracy ${ }^{54}$. Contradictions teared apart the Antonian party and the majority of adherents of East triumvir demanded from him removal from their camp Cleopatra. Her presence discredited Antony in the eyes of Roman society and make plausible associated with it accusations against Octavian.

However, Antony could not do it for military and material reasons. According to some researchers, first, it would weaken his army, because it included Egyptian troops, subordinated to Cleopatra. Secondly, she provided great financial support to the dictator. Finally, he would have lost not only Egyptian, but also all Eastern resources ${ }^{55}$.

Thus, the propaganda campaign and the military actions that followed it, which ended with a grandiose naval battle at the Cape Actium on September 2, 31 BC, actually brought Octavian victory and determined the further development of the Roman Empire for centuries to come. On the way to power, he, like Julius Caesar, primarily relied on his loyal legions; however, taking into account the experience of his predecessor, he was conscious that the military dictatorship as a prototype of the Hellenistic monarchy could not be a solid foundation of power in the conditions of still strong vitality of Republican traditions in Roman society. Therefore, in many respects the coming to power provided him the slogan 'Pax Romana' proclaimed by him. All the privileged strata of Roman society, striving for consolidation, enthusiastically picked up this slogan and supported Octavian. Under this slogan, according to V.N. Dyakov, 'His goal was to turn the soldier's dictatorship into a paramilitary slave-owning's dictatorship'56. But to give strength and viability to this dictatorship Octavian needed to legalize his power, what in the conditions of strong opposition of the Republican party in the Senate was very difficult to do.

According to the supporters of the formal juridical approach, one of the most important problems of the legalization of Octavian's power was the provision of legality of his dictatorial powers, because on the last day of December $33 \mathrm{BC}$ the term of the triumvirate has expired. Because of this, all the actions of Octavian in $32 \mathrm{BC}$ from a legal point of view, many researchers are considered as illegal, because they fallen under the qualification of a coup d'état ${ }^{57}$. But some of scientists believes that Octavian acted within the framework of the law, because he did not pass the official procedure of resignation ${ }^{58}$. This opinion is based on the fact

\footnotetext{
${ }^{54}$ SYME 1939, 239, 266

5 CRAWFORD 1978, 175; KROMAYER 1898, 51.

56 DYAKOV 1952, 653-654.

WHIPPER 1923，358; FERRERO 1909，379; DRUMAN 1899, 326; HAMMOND 1933, 20; HUZAR 1978, 209; LEVI 1951, 37; LÖWENSTEIN 1985, 535; SEYFARTH 1975, 44

${ }^{58}$ It should be noted that the date of completion of the triumvirate remains in question. The end of the triumvirate some researchers refer to December 33 BC, others-to December 32 BC. It is only known that Octavian did not officially resign his powers as triumvir, but did not use them either.
} 
that Octavian was very popular among the plebeians for help the people, and also as a result of glorifying himself and his memory through the use of the methods of the populars, which he used in the struggle for power to exert pressure on the Senate ${ }^{59}$

However, it seems the issue of the legality of Octavian dictatorial powers little concerned Roman citizens, because the ancient authors practically did not mention about it. According to the author of this article, the explanation of it lies in the mentality of Roman society. Obviously, the Romans believed that the oath of the legions, preserved Octavian right command even after the liquidation of the Triumvirate and, consequently, he continued to be a political leader and a dictator de facto.

Together with that, his position was rather unsteady. To take a leading place in the state system of Rome, he needed to legalize his power. As appears, a huge role in this the promulgation of the Antony's will have played, which, according to Dion Cassius, made a revolution in public consciousness and led to confusion even supporters of Antony. Because of it, the Senate deprived him the Consulate and all other powers ${ }^{60}$.

The most important result of it was Octavian became the owner of the highest credibility (auctoritas). In a result of it, as he wrote in 'Res gestae', 'whole Italy voluntarily oath allegiance to me and demanded I be the leader in the war in which I won a victory near the Cape Actium. The same oath gave me the provinces of Gaul, Spain, Africa, Sicily, Sardinia' ${ }^{61}$. According to a number of scientists, this oath, which corresponded to the traditional for the Roman Republic institution of patronage - clientele, made him the patron of all the inhabitants of Italy and the provinces and became an important legal basis for his power ${ }^{62}$. This oath became a precedent; it later began to bring all the inhabitants of the Roman Empire at the accession to the throne of the next emperors. Auctoritas was not before Octavian legal the basis of power. Only with him, it began to acquire state legal significance, because the Senate in $27 \mathrm{BC}$ was forced give Octavian special powers. This oath became a precedent; it later began to bring all the inhabitants of the Roman Empire at the accession to the throne of the next emperors. Auctoritas was not before Octavian legal the basis of power. Only with him, it began to acquire state legal significance, because the Senate in $27 \mathrm{BC}$ was forced give Octavian special powers - Cura rei publicae et tutella universa, that is, the care and custody of the Roman state. It, obviously, explains the fact the Senate presented him and the title 'pater patriae'63.

However, in the author's view, at that time the auctoritas and the related oath of allegiance of legions and inhabitants of Italy and the provinces were highly illusory way of legalizing Supreme power. Its legality in the Roman Republic, about protection of the traditional foundations of which Octavian proclaimed in his slogan, needed a firm legal

\footnotetext{
SOUTHERN 1998, 94. CAH 1996, 67-68.

59 DETTENHOFER 2000,114-127, 209-210 and Reviews of this book: BUCHER 2003, 417-419; HURLET 2003, 192-195.

${ }^{60}$ Dio Cass. L. 4. 2-3.

${ }^{61}$ RGDA. 25.

62 FADINGER1969, 288; HAMMOND 1933, 20; PARIBENI 1950, 322; SYME 2002, 288.

63 Dio Cass. LIII. 17.
}

basis, that is - the Republican legislation. For this, Octavian had to achieve the possession of the power of imperium, and without territorial boundaries (imperium infinitum), and full power of people tribune (tribunicia potestas). In this regard, in $30 \mathrm{BC}$ the Senate confirmed its senatus consulto from $36 \mathrm{BC}$, according to which Octavian was granted lifetime authority of the tribune (tribunicia potestas) ${ }^{64}$. Here also played a role factor of the civil war, as a formal reason for this was his victory over the son of Pompey.

At the same time, it is hardly possible to see this act was the beginning of the usurpation state power by Octavian, since in the scientific literature the question the prerogatives Augustus as tribune is interpreting ambiguously due to differences in historical sources. Thus, at Dion Cassius, on the one hand, it is says that he received the tribune power in $23 \mathrm{BC}$, on the other - in $30 \mathrm{BC}$. He was telling too that the sacred inviolability of tribune and the place on the bench for Tribunes in the Senate he was granted in 36 BC. Also about it, Appian and Orosius were saying ${ }^{65}$.

An explanation of these sources gave T. Mommsen, I. Kromayer, E. Kornemann and A. Premershtein. P. de Franchisci made their generalization ${ }^{66}$. T. Mommsen, the main attention paid to Appian and Orosius. He believed that Octavian received the complete tribunicia potestas in $36 \mathrm{BC}$, the jurisdiction of which was enlarged one thousand paces from the city limits in $30 \mathrm{BC}$. His tribunicia potestas became annual only in $23 \mathrm{BC}^{67}$. A. Premerstein was agreed with the opinion of Mommsen, but made a clause that in 30 BC Octavian received an extended right of assistance. In addition, in his opinion, in 27, Octavian refused not only from the tribune's power granted to him in 36, but also from his extraordinary powers. From 23, he again became the owner of a annually renewable full tribunicia potestas ${ }^{68}$. E. Cornemann believed the full tribune power was given to Octavian in $30 \mathrm{BC}$, and in $23 \mathrm{BC}$, it became annual ${ }^{69}$. $\mathrm{H}$. Dessau and R. Syme claim that all the rights and privileges of the people's tribune Octavian received a $30 \mathrm{y}$. At the same time, R. Syme explains the lack of epigraphic data on his tribunicia potestas until 23 by the fact that August at this time relatively rarely resorted to the use of the opportunities of the tribunate ${ }^{70}$. It also considers and E. Gruen ${ }^{71}$.

Thus, the consensus about genesis power of Octavian as tribune researchers have not, however most agree that full power Octavian received in $23 \mathrm{BC}$. This is consistent with the statement of Augustus himself, who claimed that in 14 he became the tribune for the 37th time ${ }^{72}$. Completely agree with this, many modern researchers who believe that Octavian accepted tribunicia potestas in full in 23, in 36 and 30 years, he had been granted only separate powers, such as sacrosanctitas and jus auxilii ${ }^{73}$.

\footnotetext{
${ }^{64}$ Dio Cass. LI. 19. 5-6.

${ }^{65}$ Dio Cass. XLIX, 15, 5-6; Appian. V, 132; Paulus Orosius. VI, 18, 34.

${ }^{66}$ FRANCISCI 1941, 12-14,

67 MOMMSEN 1887, 872.

${ }^{68}$ PREMERSTEIN 1937, 266.

${ }^{69}$ KORNEMANN 1945, 310-316.

${ }^{70}$ DESSAU 1924, 53; SYME 1939, 336.

${ }^{1}$ GRUEN 2007, 39

Res Gestae. 4, 4.

${ }^{73}$ EGOROV 1985, 94; EGOROV 1992, 254; GRIMM 1900-1901, 85, 132-133; MASYKIN 1949, 398-399; WICKERT 1954, 2283-2287; WICKERT 1974, 73 74; OSGOOD 2006; RIDLEY 2003; SUMI 2005; SWAN 2004 and others.
} 
Based on above, we can state the tribune power was granted Augustus phased in 36, 30 and 23 BC. Full tribunicia potestas he received in $23 \mathrm{BC}$, but here the question arises, why it was happening phased? The answer, in the author's view, is that, on the one hand, his power was separated from the post - he was a triumvir and Consul, which was incompatible with the office of tribune. On the other hand, Octavian did not belong to the plebeian stratum, from the elected representatives of which according the Republican Constitution a tribunate was forming.

In this regard, in $36 \mathrm{BC}$, when Octavian was still part of the triumviri reipublicae constituendae, he was only able to achieve life-long granting of such prerogatives of the tribunicia potestas as the tribune immunity (sacrosanctus) and the right to the tribune bench in the Senate. Sacrosanctus provided him the personal inviolability, as well as an independent position in Senate; as a result, he did not bear any responsibility to him. It was due to his promise to resign the extraordinary powers of a triumvir this year. Octavian seemingly was afraid the senators might demand from him, as a former public official an account of his actions ${ }^{74}$.

In $30 \mathrm{BC}$, Octavian as the consular power owner also had no right to the full tribune power. However, the Senate was forced to grant specifically for his extended right to protection and assistance (jus auxilii), which extended beyond the city limit, and which, according to Tacitus, was the main basis of the tribunicia potestas ${ }^{75}$.

In this regard, the question arises, why Octavian, not a member of the tribunate collegium, so eager to get the full tribune power and later even refused the consular power? The answer, in the author's opinion, may be as follows. First, the possession of tribune's rights were closely connected to the ideological aspect consolidation of Octavian at the pinnacle of state power, because the tribune's authority largely had a sacral character, as mentioned by the August himself. Tacitus, who, according to O. Pettit, gave Augustus the characterization of a manipulative monarch, regarded his tribunate power as the summi fastigii uocabulum of the Emperor, as the highest pinnacle of power in Rome ${ }^{76}$.

In addition, he received the right not only to convene the people's assemblies and meetings of the Senate, but also to veto any Senate and magistrate decisions ${ }^{77}$. However, other tribunes could hardly veto his own rulings because his status and auctoritas were too high ${ }^{78}$. In the opinion Pettit, for Octavian, the veto played the most significant role on his path to power ${ }^{79}$.

Secondly, the Princeps Consul could hardly be satisfied with the fact that his colleague on the Consulate had the same powers as himself. Third, the tribunicia potestas was opening the way for its owner to obtain additional powers belonging to the consuls and censors. Octavian received the right to convene the Senate, to make reports during its meetings, to introduce bills. Thus, according to Y. Y. Mezheritskii, his further refusal of the authorities of the

\footnotetext{
74 SHAKOTKO 1987, 56.

75 Tac. Ann. Y, !.

76 PETTIT 2011, 28.

77 VERVAET 2010, 137

78 MOUSOURAKIS 2007, 50

79 PETTIT 2011, 28.
}

Consul he successfully compensated for by the power of the tribune ${ }^{80}$.

The third and final stage of Octavian's reception of the full power of tribune, as already mentioned, came in $23 \mathrm{BC}$. His competence was expanded by the addition of the right of intercession, the right of appeal to the people and the council with the Senate. In addition, he became the owner derivative rights had by all magistrates - jus primae relationis, jus correctionis, jurisdictio. Subsequently, in a year's time, Octavian got the right to be arbitrary, at its sole discretion, the convening of the Senate and the presidency on it.

Regarding the approval about convening of the Senate and the connection between the tribune power and jus consulendi senatus, the opinions of several researchers differ. For example, L. Wickert believed that the right to convene the Senate was not at all within the limits competence of the tribunate ${ }^{81}$. However, it is difficult to agree, because it contradicts the sources. In particular, according to Tacitus ${ }^{82}$, Tiberius used the tribunicia potestas to convene the Senate in connection with the death of Augustus. Thus, in the author's view, the tribunes had such powers in principle, but apparently the tribunicia potestas did not give them the right to arbitrarily convene the Senate on any occasion and at any time. Thus, the acquisition of the powers of the people's tribune by Octavian in full gave him the opportunity to exert his influence on all sides of public management. At the same time, such influence can hardly be considered as a sole rule and transition to the monarchical form of the state, since the position of the Senate in it remained strong enough.

Senate constitutional activity to the strengthening power of the Octavian is understandable. The senators understood that the Caesar governance set a precedent, and based on the precedent Octavian had to have at least the same imperious prerogatives as his predecessor. In addition, he illegally removed from power his colleague in the triumvirate Lepidus, M. Emilia, and war was approaching in the country with another Caesarian opponent - Anthony. The senators understood that the tribune powers that had previously Julius Caesar, and that Octavian received in $36 \mathrm{BC}$ as a precedent, in the conditions of civil strife were necessary for the legalization of his power ${ }^{83}$. The act of acceptance by Octavian in $30 \mathrm{BC}$ of the tribune right of aid (auxilium) served the same purpose. This right the Senate granted him in absentia when, after the victory over M. Antony, he still remained in the East. According to Mikhailovsky, auxilium went beyond the prerogatives similar power of the Gaius Caesar, so it was no longer a precedent. However, initially representing the shaping part the power of Tribune, it became an important addition to the already existing rights of August as Tribune and had to provide him the support of the population of all Italy ${ }^{84}$. In this regard, the act of acceptance by him in $23 \mathrm{BC}$ the full power of Tribune with the right to the tribune bench in the Senate, the sacred inviolability and the right of assistance from a formal point of view looks quite logical and reasonable. Thanks to the lifelong

\footnotetext{
MEEZHERITSKY 1994, 261

WICKERT 1975, 73-74

2 Tac. Ann., 2.

83 MIKHAILOVSKY 2012, 75.

${ }^{84}$ MIKHAILOVSKY 2012, 76.
} 
„tribunicia potestas" Octavian received the right of legislative initiative, intervention in the orders of magistrates, the convening of the Senate and civil management. In addition, in 29 BC, after a magnificent triumph arranged for him by the Senate in connection with the victory over Anthony, Octavian, according to the law proposed by the Senate and enthusiastically supported by all Roman comitias, received the title of Emperor. According to Dion, emperors practiced the renewal the terms of their authorities ${ }^{85}$. Based on this, we can assume that Octavian in $23 \mathrm{BC}$ during the annual renewal of his already existed powers of tribune had the possibility to get a full tribune authority.

However, here the question arises. Why, as under Caesar, the Senate went to grant Octavian powers of tribune? After all, it by this in principle had to weaken its position in system of the power. The answer seems to be twofold. First, to $23 \mathrm{BC}$ the Senate was giving Octavian not title but the powers of the tribune, and not fully, but only partially and in stages, therefore the role of the Senate in government as a whole did not belittle. On the other hand, the senators could not understand that giving Octavian civilian in its content prerogatives of tribune, unrelated to military administration, was to symbolize his desire to establish the long-awaited peace and tranquility in the country, to restore traditional state institutions and forms of life, that the Senate sought and the population, tired of civil wars waited. This, undoubtedly, was to enhance the popularity not only of the Princeps, but also of the Senate, especially considering the fact that, according to Dion Cassius, in his speech before the Senate on January 13, 27 BC, Octavian expressed his willingness to resign all emergency powers in favor of the Senate and the people ${ }^{86}$.

However, it can hardly suppose that the partially and in stages granting powers of the tribune to Octavian, like Caesar, meant that they had separate character. The answer to this question seem to author we can found in the so-called "constitution "of Sulla. We know that Sulla took away from tribune the right to claim in the future for any other magistracy. He also deprived the tribunes of the right to submit bills to the Roman comitias without their Senate approval ${ }^{87}$. This gave individual researchers reason to interpret this restriction of tribune's power as depriving the tribunes of the right to legislation at all ${ }^{88}$. However, this judgment does not seem quite correct, because there is no documentary evidence of this. Contrarily the speech of Cicero against G. Verres contains a provision that tells that the tribune Kv. Opimius, used his right of „veto"89. In this regard, a number of researchers believe that thereby he violated the alleged restriction imposed by Sulla on the intercession. However, the ancient authors are silent about it, and Caesar speaks directly about the preservation of the tribunate of this right ${ }^{90}$.

Whatever it was, it is obvious that the Sulla's "constitution" aimed at limiting the powers of the tribune

\footnotetext{
${ }^{85}$ Dio. 53, 16, 18.

${ }^{86}$ GOLDSWORTHY 2014, 231. It should be assumed that the text of Octavian's speech, given by Dion Cassius, may not be completely authentic - auth .

${ }^{87}$ App. B. C., I, 59; I, 100

${ }^{88}$ GRUEN 1974, 23.

${ }^{89}$ Cic. Verr. II, 1,155

${ }^{90}$ Gaes. B.C. $1,5,7$.
}

and the attractiveness of the tribunate as a whole. Sulla by its limitations only created the appearance of this magistracy, which had lost its political importance, except the right of assistance, about what Cicero and Salustri wrote ${ }^{91}$. In the rest it has become perceive as exerting honors. The Senate, gradually and partially granting Octavian, as Caesar in his time, powers tribune, thereby demonstrated a commitment „constitution" of Sulla in relation of the detraction tribune's power. Octavian, who needed the support of the Senate, had no choice but to accept the initial rights of the tribunes, but not the title, demonstrating his unity with the Senate. The Senate, in turn, symbolized its support for the Princeps and the formal stability of the Republican government. However, the granting of individual prerogatives of tribune power to a person not associated with the holding of official post did not lay into the framework of the Republican traditions. This can be explained by the fact that the Senate, obviously, was no longer completely free in their actions and was forced to conclude with Octavian currently unknown behind-thescenes deals.

As for the power of the imperium, in 28 BC Octavian, already being Emperor, was elected by Consul for the sixth time, sharing this post with a colleague, being along with this the main holder of power ${ }^{92}$. At the same time, as you know, Octavian received the consulate the first time at 19 years old, which contradicted to Roman law, but the factor of the civil war played its decisive role. His troops, introduced in Rome, and the adoption in the Roman comitias of the law proposed by him, providing for the punishment of Caesar's murderers, cooled the indignation of Republicans in the Senate. However, the imperium of consul did not give him full power, as it was limited geographically, besides this magistracy was collegial and limited to a certain period. For dictatorial rule, it was necessary to extend the imperium to the entire territory of the state. Such power, are not limited in time and free from the intervention of colleagues, belonged to Roman proconsuls or propraetors within their provinces. This became the reason for T. Mommsen to conclude, which most researchers agree, that the imperium proconsulare was one of the foundations of the Imperial power, despite the fact that in the official title of the emperors the rank of proconsular appeared in the reign emperor Trajan only. However, Mommsen, used references to the news of Dion Cassius that the lifelong imperium proconsulare within pomeria and in all provinces Augustus received in $23 \mathrm{BC}^{93}$.

In $29 \mathrm{BC}$, Octavian became a censor. Using censorial powers, he in $28 \mathrm{BC}$, under the pretext of conducting a General census of citizens, which was not conducted from 70 BC, along with his colleague, Consul Agrippa carried out a purge of the Senate (in the following he did it two more times), bringing the number of its members to the primary amount. However, why did he do it, to strengthen the Supreme body of the Republic, or to strengthen his power?

At first glance, we cannot reproach Octavian for selfish purposes, because, according to Suetonius, „The grown Senate had gotten too big and turned into an ugly and disorderly crowd amounted more than a thousand members,

\footnotetext{
Cic. De leg., III, IX, 22; Sallust. Fr. Hist., III, 48, 3.

92 ECK 2007, 50-52.

${ }_{93}$ MOMMSEN 1917, 342.
} 
and among them were the most unworthy, adopted after the death of Caesar on acquaintance or for a bribe... He returned to the Senate the former composition and shine ${ }^{\text {"94 }}$.

However, on the other side, in the updated Senate, Octavian's name was put first on the list of senators, making him the speaker or the first Senator (princeps senatus) ${ }^{95}$. Thus, he acquired not only the honorary title, as previously thought, but essentially became the first person in the state. None of the senators was now able to achieve greater popularity than he, because according to the law on fighting extravagance, arranged by someone spectacle could not in its scale and brilliance to surpass the spectacle of Princeps.

Nevertheless, it seems the aristocracy benefited from the power of the Princeps, because peace was established in the country, the revolt of slaves was suppressed and in general, the privileged position of the senatorial class was restored. At the same time, according to Suetonius, „...in Senate he created the Council, which was chosen for half a year by lot: in it he discussed affairs before presenting them to the complete Senate. On matters of particular importance, he questioned the senators not in order and custom, but at his discretion". This gave grounds to some researchers, in particular S. Kim to conclude that the Senate began to have only a fiction of power ${ }^{96}$.

However, this conclusion can hardly be fully accepted. First, the Council elected by lot to drafting legislation could hardly detract the role of the Senate. It seems to have only contributed to improving the efficiency and quality of law making. It can be confirmed by the presence of specialized committees in the legislative bodies of modern States, as a prototype of which can be considered and the Council created by Octavian.

Secondly, if Octavian really wanted to diminish the role of the Senate in state life, then why did he restore its powers? To this end, he revived the Sulla law, which returned to the "fathers-senators" their authority (patrum auctoritas) in the field of legislation. From now on, as under Sulla, any law adopted in the Romana ad comitia needed the approval of the Senate, as well as any bill of the magistrates. In addition, as already mentioned, all the bills were preparing by a special Senate Committee consisting of the highest magistrates and 15 senators elected by lot. Augustus in addition conducted through the Roman comitias a law by which the senatorial estate was removed from the jurisdiction of the Roman courts, the right to proceedings against senators was transferred to the Senate itself. According to Dion Cassius, the court carried out members of the Senate Committee (the highest magistrates and 15 senators) headed by Augustus ${ }^{97}$.

Thus, it seems that during this period the Senate, as the personification of the Republican form of government, has not yet lost its importance and role in the governance of the state. Many researchers agree with this. As it known, T. Mommsen believed that in the period of the Principate a diarchy of power between the Senate and Princeps established in the Roman state ${ }^{98}$. With this statement, it

\footnotetext{
${ }_{94}$ Suet. Aug. II. 35.

${ }_{95}$ Dio. LIII, 1.

96 KIM 2001, 57.

${ }_{97}$ Dio. 53.21.

98 MOMMSEN 1871-1887, 1255.
}

is possible completely to agree, because, according to the author, Republican state institutions in this period were the Foundation of the state and the such forms of the government as Principate.

E. Meyer in his works argued that the Senate continued to have full power, and Princeps as the first citizen of the Republic was its protector and custodian ${ }^{99}$. Obviously, related to this is the fact that in $27 \mathrm{BC}$ the Senate gave Octavian special powers related to the care and guardianship of public affairs (cura et tutela rei publicae universae). G. Ferrero in his book defended the idea that Augustus really restored to the Republic with a corresponding role of the Senate in it. However, due to the passivity of the aristocracy, which no longer sought to perform their civic duties, inevitably there was a need to establish sole power ${ }^{100}$. Finally, according to E. Grim, at first the state system was closer to the Republic, and only at the end - turned essentially into an absolute monarchy ${ }^{101}$.

Thus, to say that in the period of his Principate Octavian Augustus sought to monarchical form of government and obtain odious in the eyes of the Roman citizens of the Royal title, obviously, it is impossible. According to Suetonius, „People offered him dictatorial power incessantly, but he kneels, dropping his toga from his shoulders, exposing his chest, begged to rid him from this. The title "sovereign“ he always feared as an insult and shame“102.

At this time, it seems that Octavian's aspirations were aiming at preserving and strengthening the shaky foundations of republican statehood, which could only be done under conditions of centralization of power and on the base of his personal charisma. It allowed him to establish patronage over Roman citizens and enjoy their support. According to I.Sh. Shifman, as a political leader, he clearly surpassed previous and contemporary politicians, even such prominent as Caesar and Cicero. His authoritarianism was conditioned to the fact that all his political and social activities corresponded to the challenges of his time, and he himself was the product and embodiment of his era, associated with the dying away of the statehood of the polis as embodiment of city-state ${ }^{103}$.

According to the author, being a far-sighted and subtle politician, far surpasses his contemporaries in assessing the current situation, Augustus better than others understood the depth and complexity of the socio-economic and political changes in Roman society. He, obviously, was aware that the formation of a new slave-owning oligarchy, interested in establishing a durable peace associated with the strengthening and centralization of power in the state, and craving for new seizures of land and slaves, required new approaches to management.

Civil wars have shown that the consolidation of society and the strengthening of state basis have already become impossible within the framework of the old polis organization of power, split between the more and more deviating from the management Senate, magistrates and

\footnotetext{
99 MEYER 1903, 441-492.

100 FERRRO 1998, 445-466

101 GRIMM 1900, 48.

102 SUETONIUS 1966, 65.

${ }^{103}$ SHIFMAN1990, 3, 6, 95, 96.
} 
comitia, which became too lost their former significance. The traditional system of checks and balances between these branches of government ceased to function, and for effective government, it became necessary to concentrate all or most of the power prerogatives of these branches in one hand, but without the sharp change of traditional state basis. However, in order to achieve this goal, Guy Octavian had maximally to strengthen his authority between different sectors of society in order to obtain their support in pursuing his policy. This support was supposed to provide him with not only formal legalization, but also the actual legitimization of his power.

\section{REFERENCES:}

\section{AKHIEV 2009}

Akhiev, S. N., Ptolemy Caesar in promoting triumviri, The Ancient World and Archaeology 13, 242-248.

\section{AKHIEV 2001}

Akhiev, S. N., The image of Cleopatra in the propaganda of Octavian Actual questions of history 2, 94-101.

\section{BENGTSON 1982}

Bengtson, G., Rulers of the Hellenistic era (Moscow).

\section{BOGOMAZOVA 2012}

Bogomazova, L.N., Alexandrian gifts 34 BC. Classic Byzantine tradition. Proceedings of the VI international scientific conference. (Belgorod: Belgorod State University), 33-34.

\section{BRAUND 1984}

Braund, D., Rome and the friendly king: the character of the client kingship. (Groom Helm, L.-Canberra; St. Martin's Press, New-York).

BROADBENT 2012

Broadbent, V., Augustus, Egypt, and Propaganda (Waterloo: University Press).

CHERNYSHOV 1994

Chernyshov, Yu. G., Socio-utopian ideas and the myth of the "Golden age" in ancient Rome. (Novosibirsk: University Press).

CHARLESWORTH 1933

Cyarlesworth, M.P., Some Fragments of the Propaganda of Mark Antony, Classical Quarterly 27, 172-177.

COOLEY 2009

Cooley, A.E., Res Gestae Divi Augustis. Text, Translation, and Commentary (Cambridge: Cambridge University Press).

CRAWFORD 1978

Crawford, M.H., The Roman Republic (London: FontanaCollins).

CROOK 1957

Crook, J., A Legal Point about Mark Antony's Will, The Journal of Roman Studies 47/1-2, 36-38.

DEBVOIS 2008

Debvois, N. K., Political history of Parthia (St. Petersburg: State University Press).

\section{DESSAU 1925}

Dessau, H., Der Staatsstreich des Jahres 52 v. Chr., Philologische Wochenschrift 35/56, 1017-1023.

DETTENHOFER 2000

Dettenhofer, M., Herrschaft und Widerstand im augusteischen Principat (Stuttgart: Franz Steiner Verlag).

\section{DRUMANN/GROEBE 1899}

Drumann, W./Groebe P., Geschichte Roms in seinem Übergange von der republikanischen zur monarchischen Verfassung (Leipzig: Börntraeger)

ECK 2007

Eck, W., The Age of Augustus. (Oxford: Wiley-Blackwell).

FADINGER 1969

Fadinger, V., Die Begründung des Prinzipats. (Bonn: R. Habelt).

\section{FADINGER 1969}

Fadinger, V., Quellen untersuchungen zur Geschichte des 2.

Triumvirats: Inaugural-Dissertation (München).

\section{FERRERO 1909}

Ferrero, G., The greatness and fall of Rome. Vol. 5. The republic of Augustus (London: William Heinemann).

\section{FRANCISCI 1941}

Francisci, P., Genesi e struttura del principato Augusteo (Roma: Reale Accademia d'Italia).

\section{GABBA 1971}

Gabba, E., The Perusine War and Triumviral Italy, Harvard Studies in Classical Philology 75, 139-160.

\section{GOLDSWORTHY 2010}

Goldsworthy, A., Antony and Cleopatra (London: Weidenfeld \& Nicolson).

\section{GOLDSWORTHY 2014}

Goldsworthy, A., Augustus. First Emperor of Rome (New Haven: Yale University Press).

\section{GURVAL 1998}

Gurval, R.A., Actium and Augustus: The Politics and Emotions of Civil War (Chicago: University of Michigan Press).

\section{GRANT 2004}

Grant, M., Cleopatra. The last of the Ptolemies (Moskow: Centrpoligraf).

\section{GRIMM 1901}

Grimm, E. D., Research on the history of the Roman Imperial power. Vol. I (St. Petersburg: Stasyulevich).

GRUEN 2007

Gruen, E., Augustus and the Making of the Principate. In: The Cambridge Companion to the Age of Augustus (Cambridge: University Press).

\section{GRUEN 1974}

Gruen, E.S., Last Generation of the Roman Republic (Berkeley: University of California Press).

\section{HAMMOND 1933}

Hammond, M., The Augustan Principate in Theory and Practice during the Julio-Claudian Period (Cambridge: Harvard University Press).

HEINEN 1969

Heinen, H., Cäsar und Kaisarion, Historia: Zeitschrift für alte Geschichte 18/2, 181-203.

HUZAR 1978

Huzar, E.G., Mark Antony. A Biography (Minneapolis: University of Minnesota Press).

KIENAST 1999

Kienast, D., Augustus. Prinzeps und Monarch (Darmstadt: Wissenschaftliche Buchgesellschaft).

KIM

Kim, S., Octavian Augustus founder of the Principate, History Publishing house the First of September 21/1, 49-58.

\section{KORNEVANN 1945}

Kornemann, E., Volkstribunat und Kaiertum. In: Koschaker, P./Wenger, L. (eds.), Festschrift für Leopold Wenger zu seinem 70. Geburtstag 2, (München: Beck), 310-316.

\section{KRIST 1997}

Krist, K., History of the Roman emperors from Augustus to Constantine. Vol.1 (Rostov-on-Don: Phoenix).

\section{KROMAYER 1898}

Kromayer, J., "Die Vorgeschichte des Krieges von Actium" LEVI 1951 Hermes Zeitschrift für Classische Philologie 33, 61-70.

Levi, M. A., Il tempo di Augusto (Florence: La Nuova Italia). LINDSAY 1936

Lindsay, J., Marc Antony, his World and his contemporaries (London: Routledge \& Sons)

LINDSAY 1971 
Lindsay, J., Cleopatra (New York: Constable \& Robinson).

LÖWENSTEIN 1985

Löwenstein, K., Die Konstitutionelle Monokratie des Augustus. In: Augustus (Darmstadt: Wissenschaftliche Buchgesellschaft), 531-556.

MARTYNOV 2007

Martynov, A. S., "Pro-Roman orientation and Imperial projects of Cleopatra VII". Historical and political studies 3-4, 362-367.

MASHKIN 1949

Mashkin, N. A., The Principate of Augustus. Origin and social essence (Moscow-Leningrad: Publishing house of the USSR Academy of Sciences).

MEIKLJOHN 1934

Meikljohn, K.W., Alexander Helios and Caesarion, Journal of Roman Studies 24/2, 191-195

MEYER 1903

Meyer, Ed., Kaiser Augustus, Historische Zeitschrift 91, 385431.

\section{MEZHERITSKY 1994}

Mezheritsky, Y. Y., Republican monarchy: metamorphoses of ideology and policy of Emperor Augustus (Moscow-Kaluga: Krasnoyarsk State Pedagogical University).

MIKHAILOVSKY 2012

Mikhailovsky, F.A., Development of the tribune powers of Octavian Augustus, Bulletin of the Moscow city pedagogical University. Series: Historical Sciences 2/10, 74-79.

MOMMSEN 1877

Mommsen, Th., Römisches Staatrecht: in 3 Bd. 2. - Abt. 2. -1877a. - S. XIV, 721-1171. Bd. 3.- Abt. 2. - 1877b. - S. XVIII, 835-1271 (Leipzig: S. Hirzel).

MOUSOURAKIS 2007

Mousourakis, G., A Legal History of Rome (Oxford: Routledge).

NIMIS 2004

Nimis, S., Egypt in Greco-Roman history and fiction, Journal of Comparative Poetics 24, 34-67.

PARIBENI 1950

Paribeni, R., L'età di Cesare e di Augusto. (Storia di Roma, V.) (Rome: Istituto di Studi Romani; Bologna: Cappelli).

PELLING 2005

Pelling, C., The Triumviral Period. In: The Cambridge Ancient History. Vol. 10: The Augustan Empire, 43 B.C. (Cambridge: University Press), 1-69.

PELLING 2001

Pelling, C., Anything truth can do, we can do better: the Cleopatra legend. In: Cleopatra of Egypt: from history to myth (London: British Museum Press), 292-301;

PETTIT 2011

Pettit, Owen P., The constitutional powers of the senate during the reign of Augustus. Masters Research thesis. School of Historical and Philosophical Studies (Melbourne: University Press).

PREMERSTEIN 1937

von Premerstein, A., Vom Werden und Wesen des Prinzipats (München: Bayerische Akademie der Wissenschaften).

REINHOLD 1981/2

Reinhold, M., The Declaration of War against Cleopatra, Classical Journal 77/2, 97-103.

REHAK 2006

Rehak, P., Imperium and Cosmos. Augustus and the Northern Campus Martius (Madison: University of Wisconsin Press).

REINHOLD 2002

Reinhold, M., Augustus' conception of himself, Studies in Classical History and Society 45, 59-69.

SANTANGELO 2007

Santangelo, F., Sulla, the Elites and the Empire: A Study of
Roman Policies in Italy and the Greek East (Leiden-Boston: Brill).

SCOTT 1929

Scott, K., Octavian's Propaganda and Antony's De Sua Ebrietate, Classical Philology 24/2, 133-141.

\section{SCOTT 1933}

Scott, K., The Political Propaganda of 44-30 BC, Memoirs of the American Academy in Rome 11, 7-49.

\section{SCULLARD 1959}

Scullard, H.H., From the Gracchi to Nero. A History of Rome from 133 B.C. to A.D. 68 (London: Methuen)

SHAKOTKO 1987

Shakotko, E. I., Tribunicia potestas as the legal basis of the civil power of the Princeps under Octavian Augustus. In: Political organization and legal systems abroad: history and modernity (Sverdlovsk), 54-60.

\section{SEYFARTH 1975}

Seyfarth, W., Römische Geschichte. Kaiserzeit 1. (Berlin: Akademie Verlag).

\section{SHIFMAN 1990}

Shifman, I. Sh., Caesar Augustus (Leningrad: Order of the red banner of Labor publishing house).

\section{SOUTHERN 1998}

Southern, R., Augustus. (London- New York: Routledge).

STEIN-HÖLKESKAMP 2013

Stein-Hölkeskamp, E., Macht, Memoria und Monumente: Marius, Sulla und der Kampf um den öffentlichen Raum, Klio 95/2, 429-446.

SUMI 2005

Sumi, G.S., Ceremony and power. Performing politics in Rome between Republic and Empire (Ann Arbor: University of Michigan Press).

SVOBODA 1932

SYME 2002

Swoboda, E., Octavian und Illyricum (Vienna: Höfels).

TARN 1932

Syme, R., The Roman Revolution (Oxford: University Press).

Tarn, W.W., Alexander Helios and the Golden Age, Journal of Roman Studies 32, 144-149.

TARN/CHARLESWORTH 1934

Tarn, W.W./Charlesworth, M.P., The War of the East against the West. The Cambridge Ancient History. Vol. 10: The Augustan Empire, 44 B. C. - A. D. 70. (Cambridge: University Press).

\section{TSIRKIN 2006}

Tsirkin, Y. B., Civil war in Rome. Defeated (St. Petersburg: State University Press).

TYLDTSLEY 2008

Tyldesley, J., Cleopatra. Last Queen of Egypt (New York, NY : Basic Books).

\section{URECHE 2014}

Ureche, P., The soldiers' morale in the Roman army, Journal of Ancient History and Archaeology 1/3, 3-7.

VAN DEN HENGEL 2009

van den Hengel, L., Imago. Romeinse keizerbeelden en de belichaming van gender (Hilversum: Verloren).

\section{VERVAET 2010}

Vervaet, F., Arrogating Despotic Power through Deceit: The Pompeian Model for Augusan Dissimulatio. In: Turner, A.J./Chong-Gossard K.O./Vervaet F.J. (eds.), The Discourse of Despotism and Deceit in the Ancient World (Leiden: Brill).

WALLMANN 1976

Wallmann, P., Zur Zusammensetzung und Haltung des Senats im Jahre 32 v.Ch., Historia 25, 305-312.

WISCERT 1954

Wickert, L., s,v, Princeps (civitatis), Real Encyclopädie vol. 22 (Stuttgart), 2283-2287. 